Genij Ortopedii. 2021. Vol. 27, no. 5. P. 578-583.

Original article

https://doi.org/10.18019/1028-4427-2021-27-5-578-583

\title{
New approaches to pediatric treatment of post-traumatic elbow contractures
}

\section{Gairat D. Bayimbetov ${ }^{1 \bowtie}$, Iskandar Yu. Khodzhanov²}

Republican Specialized Scientific-Practical Centre of Traumatology and Orthopedics, Tashkent, the Republic of Uzbekistan

${ }^{1}$ g.baimbetov@yandex.ru

2Prof.Khodjanov@mail.ru

\begin{abstract}
IIntroduction Post-traumatic elbow contracture is a severe disabling condition of childhood that interferes with both physical and psychic aspects for the child. A high rate of poor results encourages surgeons seek for better surgical treatments. Current diagnostic modalities were practical to get the clinical picture of the contracture mechanogenesis and determine the treatment strategy. The goal of the study was to review long-term results of new surgical techniques developed for post-traumatic elbow contractures in children. Material and methods The inpatient records of 102 pediatric patients with post-traumatic elbow contractures operated on with the technique offered were reviewed. All patients underwent conventional radiological, ultrasound and MSCT examinations. Results Based on the pathobiomechanics of the injured elbow a mobilization technique was developed to ensure complete bone realignment, relieve pain and allow early exercises for the joint. Postoperative lavage of the joint cavity, intra-articular administration of corticosteroids and polyvalent enzymes in the early postoperative period facilitated improved long-term outcomes of elbow contractures. All patients reported good results. Discussion Tenotomies of the lateral ligaments can be added to arthrotomy and reconstruction of articular surfaces for temporary instability of the joint to restore movement in the elbow joint in severe cases. Post-traumatic elbow contractures are accompanied by impaired biomechanics. MSCT and 3D reconstruction of bone structures is the gold standard in the diagnosis of post-traumatic elbow contractures. Conclusion Bone impingements are to be addressed and an extended mobilization of the capsular ligamentous complex be provided for complete movement recovery through partial elbow instability to be temporarily ensured. Prolonged lavage of the elbow joint can be used to prevent adhesions and allow early elbow exercises and provide improved outcomes. Keywords: elbow joint, contracture, surgical treatment, childhood
\end{abstract}

For citation: Bayimbetov G.D., Khodzhanov I.Yu. New approaches to pediatric treatment of post-traumatic elbow contractures. Genij Ortopedii, 2021, vol. 27, no 5, pp. 578-583. https://doi.org/10.18019/1028-4427-2021-27-5-578-583

\section{INTRODUCTION}

Post-traumatic elbow contracture is a severe disabling condition of childhood. Treatment of patients with the pathology remains a challenge in pediatric traumatology [1-5]. A variety of diagnostic tools and surgical techniques are reported in the literature to address the problem and improve outcomes [6-11]. Prevalence of elbow contractures in Uzbekistan sharply differs from that reported by foreign authors and accounts for $67 \%$ of all delayed musculoskeletal injuries of childhood. The main reasons for this are the delayed referrals, treatment provided by local healers and lack of qualified trauma and orthopaedic surgeons, in particular [12, 14].

Clinical, radiological, ultrasound and computed tomography methods with the specific advantages and disadvantages are used for diagnosis. Multispiral computed tomography with $5 \mathrm{D}$ reconstruction has become a breakthrough in the diagnosis of elbow joint contractures. Giving credit to the above methods of study we consider computed tomography as the preferred method of evaluation of olecranon fossa, atypical deformities of bone structures, congruence of articulating bones. Major bone impingement and atypical deformities that cause restricted movements in the elbow joint can be visualized on CT scans. Different surgical techniques based on the laws of classical traumatology are employed in treatment of elbow contractures [9, 13, 22]. Despite great efforts in the treatment of elbow joint contractures poor results are encountered in $58 \%$ of cases $[12,16,17$, 19-21].

The goal of the study was to review long-term results of new surgical techniques developed for posttraumatic elbow contractures in children.

\section{MATERIAL AND METHODS}

Inclusion criteria were:

- post-traumatic elbow contractures with limited flexion and extension measuring less than 100 degrees (according to international standards a surgery cannot be advised for a delayed elbow injury if ROM is less 100 degrees as measured when the patient is first seen at the office);

- patient younger than 18 years;

- the patient's consent to be recruited for the study.
Exclusion criteria were:

- non-traumatic contractures of the elbow joint;

- ankylosis of the elbow joint;

- infection;

- refusal of the subject to be involved in the design of the study ;

- unavailable follow-up visits.

Between 2007 and 2015, 102 pediatric patients with post-traumatic elbow contractures were treated 
at the NIITO Children's Trauma Hospital. There were 46 girls $(45 \%)$ and 56 boys (55\%) The mean age of patients was 7.5 years. Elbow contracture were caused by distal humerus fractures $(61 \%)$, fracturesdislocations $(25 \%)$ and an injury to the proximal forearm bones (14\%). Delayed referrals or treatment with local healers were observed in $35 \%$ of cases. Patients sought treatment at the hospital 3 years of the injury ( $46 \%)$, 3 years to 5 years $(23 \%)$, more than five years of trauma (11\%), and $20 \%$ received treatment at the hospital within a year after the injury. A poor quality treatment was recorded in $63 \%$ of cases due to low expertise of trauma surgeons at a local hospital. Patients underwent clinical, radiological, US and MSCT examinations using standard techniques.

Preoperative physical examination and radiological assessment revealed multicomponent post-traumatic elbow contractures. Wrinkled joint capsule and ligamentous apparatus was detected in addition to bone malunion, nonunion, false joints, etc. Secondary degenerative changes in the soft tissues of the joint were noted in cases with injuries that occurred a year ago or over. Based on the clinical and morphological manifestations of the elbow contracture, we could identify particular osseous, capsular, ligamentous and muscular components that affected elbow function.

Surgical technique. Lateral ligaments of the elbow joint were dissected using two lateral approaches, the capsule mobilized along the perimeter of the joint, and impingements were surgically eliminated. The ligaments and the capsule were not sutured at the end of the operation. A vinyl tube was used for the drainage. Prolonged lavage of the elbow was performed in the early postoperative period using a pre-installed polyethylene tube. Early postoperative administration of corticosteroids was followed by enzymic preparations (chymotrypsin or cucumazim). Prolonged lavage was practical for removal of small bone pieces and soft-tissue detritus from the joint cavity to avoid adhesions and paraarticular ossifications.

The digital data processing was performed with a SATATOM-8 personal computer. Outcome measures included the Russian version of the DASH questionnaire (The Disabilities of the Arm, Shoulder and Hand) and the Bromderg and Morrey grading scale. The research was approved by the local ethics committee and was conducted in accordance with the ethical standards declared in the Helsinki Declaration. Informed consent was obtained from the patients.

\section{RESULTS}

Long-term results of treatment were studied in all the cases $(n=102)$ during the period of one year and a half to two years. The length of inpatient treatment was 20-25 days and was associated with the daily prolonged lavage of the elbow joint to be carried out in the hospital. All patients reported pain postoperatively. Pain intensity had a wave-like course with primary and secondary hyperalgesia of moderate severity observed in the first 5-7 postoperative days in all cases. The pain was likely to be caused by decompression of the elbow joint and prolonged lavage that was helpful in preventing significant postoperative edema. The pain decreased to a minimum after 5-7 postoperative days. Patients could start working on ROM in the elbow with the drainage tube removed after 23-25 postoperative days which resulted in the resumption of pain. Pain improved with the final amplitude of movement achieved. Postoperative complications included an injury to the ulnar nerve in the form of neuropraxia $(n=13)$, neurotmesis of about $5 \mathrm{~cm}(\mathrm{n}=1)$ with the ulnar nerve wound around the rotating head of a drill as a result of a technical error. The neurological deficiency was arrested due to adequate therapy within 6 months. Inflammation at the drainage tube $(n=27)$ developed due to bacterial contamination of a polyurethane tube that stayed in the joint cavity for a long time. Infection cases were resolved shortly with appropriate antibacterial therapy. Patients could start exercising the elbow joint after 3-5 postoperative days and then continue supervised rehabilitation at the regional rehabilitation centers at the place of residence. Rehabilitation of the patients and the dynamics in the amplitude of elbow movements were adjusted by local rehabilitologists and the attending physician. Patients treated with the method could regain ROM intraoperatively by $90-100 \%$ of the norm. In addition to that, compliance of the patients was controlled in outpatient settings after the patient was discharged from the hospital. Outcomes evaluated with Bromderg\&Morrey grading system and DASH (Music\&Sport) adjusted for childhood appeared to be identical (Tables 1, 2).

Table 1

Distribution of patients evaluated with Bromderg\&Morrey grading system

\begin{tabular}{|l|c|c|}
\hline \multirow{2}{*}{ Scores } & \multicolumn{2}{|c|}{ Number of patients } \\
\cline { 2 - 3 } & abs. number & $\%$ \\
\hline $95-100$ & 72 & 70.6 \\
\hline $80-94$ & 24 & 23.5 \\
\hline $60-75$ & 6 & 5.9 \\
\hline below 60 & 0 & 0 \\
\hline Total & 102 & 100 \\
\hline
\end{tabular}

Table 2

Distribution of patients evaluated with DASH (Music\&Sport)

\begin{tabular}{|l|c|c|}
\hline \multirow{2}{*}{ Scores } & \multicolumn{2}{|c|}{ Number of patients } \\
\cline { 2 - 3 } & abs. number & $\%$ \\
\hline $20-23$ & 72 & 70.6 \\
\hline $30-45$ & 24 & 23.5 \\
\hline $55-65$ & 6 & 5.9 \\
\hline Total & 102 & 100 \\
\hline
\end{tabular}


Twenty four patients with an injury of greater than 3 years showed good results with atypical deformity partially corrected and could improve the ROM to $80 \%$ of the physiological level after arthroplastic interventions. These patients demonstrated no compliance during rehabilitation program. Severe impingement in six cases with an injury of greater than five years could not be completely repaired, and the patients could regain ROM in the elbow by less than $50 \%$ with the outcomes rated as fair. The patients also had severely shortened muscles with significantly reduced muscle strength.

\section{DISCUSSION}

Impaired physiological function of muscle contractility was shown to result in muscles degenerating into connective tissue. Nonphysiological bone structures continued to grow correcting residual displacements, on the one hand, and leading to atypical bone deformities, on the other hand. Over time, the original injury to the bones of the elbow joint was difficult to identify in some cases. The majority of patients showed a volumetric deficiency and olecranon and coronoid deformities that were mostly realigned with restored anatomy of juxta- and intra-articular fractures. Rotational alignment normally resulted in asymmetric correction of olecranon and coronoid deformities and led to volumetric deformities and, subsequently, to limited ROM in the elbow joint. Ulnar malunion could be eliminated over time in delayed fracture-dislocations, and secondary atypical deformity was noted to develop with the radial head unreduced due to the loss of a natural growth stimulator (the head of the humeral condyle). Atypical hypertrophy was observed in most cases due to the high growth potential of the olecranon and coronoid processes and caused disproportioned anatomy with resultant impingement. Volumetric trochlear deficiency was seen even in a partial injury with osteoepiphyseolysis of the condyle of the humeral head. The trochlea is known to be located between the epicondyles, and is dependent on the nutrition. The blood supply is severely impaired with broken trochlea with resultant delayed growth and volumetric deficiency. Olecranon used to collapse to the distal humerus due to a decreased trochlear volume that causes bone incongruence of the brachioradial joint and prevents the movements of the radial head. The radial head is to be resected in the cases for greater ROM by reducing the friction pairs (Fig. 1, 2).

G.I. Zhabina [1], V.N. Merkulova [3], A.I. Kondratova [6], P.U. Urinbaev [12], Ya.N. Proshchenko [14] and Sh.Kh. Turakulova [15] reported results of the treatment in children with elbow contractures rated as excellent in 21-23\%; good in 26-45\%; fair in $12-$ $60 \%$ and poor in $12-19 \%$. Our series showed $55 \%$ excellent, $25 \%$ good and $20 \%$ fair results with no poor outcomes to report. The mean elbow ROM reported in English-language sources [9-11, 17-22] increased from $10^{\circ}$ to $53^{\circ}$ in $50-85 \%$ of pediatric patients after surgical treatment of contractures at a long term with the mean ROM measuring $50-70^{\circ}$ prior to arthroplastic intervention. The mean elbow ROM in our series was $15-90^{\circ}$ and $35-90^{\circ}$ at a long term.
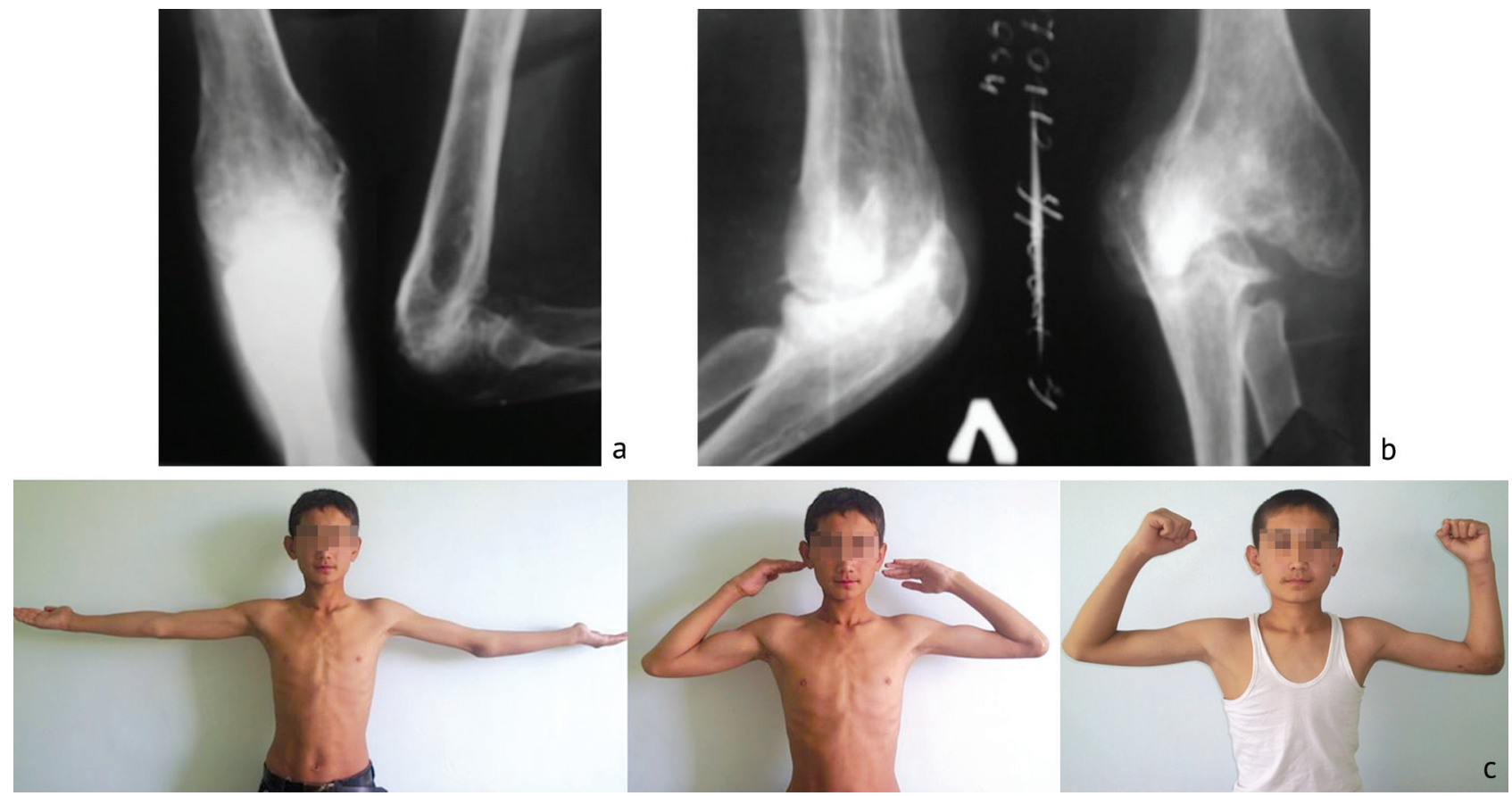

Fig. 1 Radiographs and photograph of a 14-year-old patient with post-traumatic elbow contracture resulting from an injury that occurred 5 years ago. Arthroplastic surgery was performed with resection of the radial head: (a) two views of preoperative radiographs; (b) two views of postoperative radiographs; (c) functional result at a 14-month follow-up 

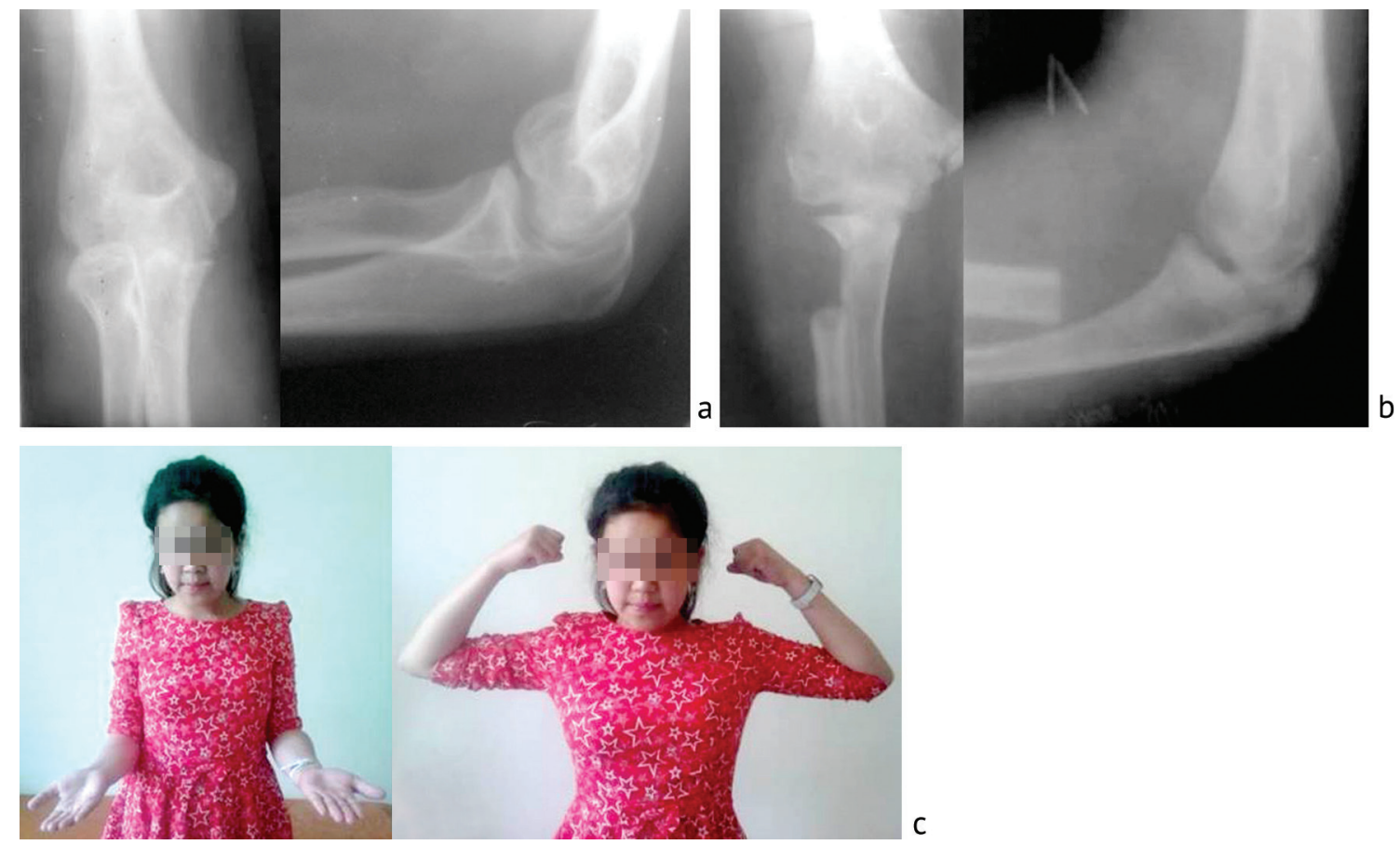

Fig. 2 Radiographs and photograph of a 15-year-old patient with post-traumatic flexion-extension elbow contracture resulting from an injury that occurred 4 years ago. Arthroplastic surgery was performed with resection of the radial head: (a) two views of preoperative radiographs; (b) two views of postoperative radiographs; (c) functional result at a long term

We suggest that the improved outcomes of posttraumatic elbow contractures depend on many factors including the interval between an injury and surgical procedure, the pattern of anatomical trauma, the extent of biomechanical changes and arthrofibrosis, preoperative ROM and comprehensive rehabilitation program, etc. Treatment of post-traumatic elbow contractures is time-consuming and is the challenge. Outcomes would be dependent on adequate diagnosis made, determination of mechanogenesis identified in every particular case and, finally, the extended elbow mobilization. The results obtained in all patients were $12-15 \%$ better than the results reported by other researchers. Improved outcomes obtained in our series resulted from extended arthrolysis, creation of temporary partial instability, decreased articulations in the elbow joint due to resected radial head, infection arrest, prolonged evacuation of inflammatory fluid from the joint cavity until the infection completely resolved and a continuous course of non-violent physical therapy. Elbow contractures usually result in shrinked capsular-ligamentous complex with impaired elasticity. To prevent this, we performed extended arthrolysis along the perimeter of the joint to provide temporary elbow instability that was important for the resolution of the contracture and pain relief during exercises in the postoperative period.

Children who are not engaged in labor activity are not concerned with elbow instability, and the apparent progress of increased elbow ROM is encouraging. Although resection of the radial head that provides lateral stability for the elbow is not advisable for pediatric population in functioning growth plate the deformity and osteophytes can seriously affect motion in the joint. Growth arrest can occur when there is damage to a growth plate resulting from a fracture or prolonged absence of joint function. Volumetric impairment of the humeral trochlea can lead to the impaired elbow function in most cases due to impingement of three articulations, and resection of the radial head is the only solution for the contracture to allow motion with less number of articulations.

Based on clinical and radiological studies the pathogenesis of pediatric elbow contractures can be presented as follows. Malunion or nonunion can develop with failures of elbow fracture repair and the ROM severely impaired due to pain and bone instability followed by malaligment. Adhesions result from restricted movements in the elbow joint the capsular ligamentous complex and lead to secondary degeneration in the joint tissues. In addition to that, prolonged restriction of movements affects the isotonic muscles' contractility with maintained isometric contractility. No patient developed pain in the muscles of interest during exercising. The volume, elasticity and plasticity of the capsule generally decreases with shrinking and stretches during exercises causing strong pain that prevents children from rehabilitation. This is deemed to be the major reason of poor outcomes. All the bone components of the contracture and the degeneration of the capsular ligamentous complex cannot be addressed simultaneously during surgery. We found it practical to dissect the lateral ligaments of the elbow, mobilize the capsule around the perimeter of the joint eliminating the impingement and apply no suture to the ligaments and the capsule at the 
end of the surgery to allow the joint being partially unstable. Connective tissue is noted to develop in children after 3-4 months due to a high regenerative capacity to get the joint stabilized. No cases of dislocated forearm bones were recorded due to the balanced humeral biceps and triceps and the isometric contraction providing sufficient stability for the elbow to allow neutral physiological exercises in the early postoperative period.

The amplitude of movement after arthroplastic procedures depended on the extent of mobilized capsular ligamentous complex, muscle retraction, tolerance to pain and the duration of contracture. In our series, the maximum ROM in the elbow joint achieved was $50-60^{\circ}$. The mean ROM achieved by the patients was $30-35^{\circ}$. No motion in the elbow was recommended in the early postoperative period of 3 to 5 days of aseptic inflammatory phase of postoperative healing. Active movements was allowed with the edema resolved and remained within the same range during three postoperative months. Patients with more extended mobilization could increase ROM by $20-30^{\circ}$ from 3 to 6 postoperative months. Patients with undermobilized elbow showed decreased ROM by an average of $50 \%$. With comprehensive course of mechanotherapy and the use of polyvalent drugs patients could improve the ROM at 12 months reaching a maximum ROM at 14 16 months. Philosophy of pediatric surgical treatment of elbow contractures was created based on research and clinical results to address bone impingements through extended mobilization and prolonged lavage of the elbow joint. Temporary elbow instability was shown to be practical for regaining ROM in the elbow joint to provide higher quality of life for a patient.

\section{CONCLUSION}

Bone impingements are to be addressed and an extended mobilization of the capsular ligamentous complex be provided for complete movement recovery through partial elbow instability to be

temporarily ensured. Prolonged lavage of the elbow joint can be used to prevent adhesions and allow early elbow exercises and provide improved outcomes.

\section{REFERENCES}

1. Zhabin G.I. Mobiliziruiushchie operatsii pri posttravmaticheskikh kontrakturakh loktevogo sustava u vzroslykh [Mobilizing surgeries for posttraumatic contractures of the elbow in adults]. Travmatologiia i Ortopediia Rossii, 1995, no. 5, pp. 36-39. (in Russian)

2. Kliuchevskii V.V., Hassan Ben El Khafi Kh. Profilaktika kontraktur loktevogo sustava pri lechenii perelomov distalnogo segmenta plechevoi kosti [The elbow contracture prevention in treatment of humeral distal segment fractures]. Genij Ortopedii, 2010, no. 2 , pp. 74-78. (in Russian)

3. Merkulov V.N., Dergachev D.A., Dorokhin A.I. Artroplastika pri lechenii posttravmaticheskikh kontraktur i ankilozov loktevogo sustava u detei [Arthroplasty in treatment of the elbow posttraumatic contractures and ankyloses in children]. Detskaia Khirurgiia, 2014, no. 4, pp. 34-38. (in Russian)

4. Oganesian O.V., Muradian D.R. Oshibki i oslozhneniia pri vosstanovlenii formy i funktsii loktevogo sustava s ispolzovaniem sharnirno-distraktsionnogo apparata [Errors and complications in restoring the shape and function of the elbow joint using a hingedistraction apparatus]. Vestnik Travmatologii i Ortopedii im. N.N. Priorova, 2008, no. 3, pp. 33-42. (in Russian)

5. Kalantyrskaia V.A., Kliuchevskii V.V., Perova V.A., Piskun M.S. Preduprezhdenie kontraktur pri lechenii povrezhdenii loktevogo sustava [Contracture prevention in treatment of the elbow injuries]. Politravma, 2015, no. 2, pp. 50-58. (in Russian)

6. Kondratov A.B., Beziazychnyi V.I. Posttravmaticheskie kontraktury i ankilozy loktevogo sustava i ikh operativnoe lechenie [Posttraumatic contractures and ankyloses of the elbow and their surgical treatment]. Tez. dokl. 3-i Respubl. Nauch.-prakt. Konf. travmatologov Kryma "Rekonstruktivno-vosstanovitelnaia Travmatologiia i Ortopediia" [Proceedings of the 3rd Republican Scientific Practical Conference of Crimea traumatologists "Reconstructive-and-restorative Traumatology and Orthopedics"]. Sudak, 1994, p. 45. (in Russian)

7. Oganesian O.V., Muradian D.R. Vosstanovleniia formy i funktsii loktevogo sustava (oshibki i oslozhneniia) [The restoration of the elbow shape and function (errors and complications)]. Genij Ortopedii, 2008, no. 2, pp. 71-76. (in Russian)

8. Soldatov Yu.P. Rekonstruktivno-vosstanovitelnoe lechenie posledstvii povrezhdenii loktevogo sustava s primeneniem apparata Ilizarova. Avtoref. diss. ... dokt. med. nauk [Reconstructive-and-restorative treatment of the elbow injury consequences using the Ilizarov fixator. Doct. med. sci. diss. abstr.]. Kurgan, 2004, 44 p. (in Russian)

9. Smith F.M. Surgery of the elbow. Saunders, 1972, $340 \mathrm{p}$.

10.Syed A.A., O'Flanagan J. Simultaneous bilateral elbow dislocation in an international gymnast. Br. J. Sports Med., 1999, vol. 33, no. 2, pp. 132-133. DOI: 10.1136/bjsm.33.2.132.

11.Tashjian R.Z., Katarincic J.A. Complex elbow instability. J. Am. Acad. Orthop. Surg., 2006, vol. 14, no. 5, pp. $278-286$. DOI: $10.5435 / 00124635-200605000-00003$.

12.Urinbaev P., Eranov N.F. Lechenie kontraktury loktevogo sustava u detei [Treatment of the elbow contracture in children]. Tez. Materialov Nauch.-prakt. Konf. «Aktualnye Problemy Travmatologii i Ortopedii» [Proceedings of the Scientific-and-Practical Conference "Relevant Problems of Traumatology and Orthopedics"]. Karshi, 2000, pp. 4-5. (in Russian)

13.Sheps D.M., Hildebrand K.A., Boorman R.S. Simple dislocations of the elbow: evaluation and treatment. Hand Clin., 2004, vol. 20, no. 4, pp. 389-404. DOI: 10.1016/j.hcl.2004.07.002.

14.Proshchenko Ya.N., Pozdeyeva N.A. Otdalennye rezultaty lecheniia detei s kontrakturami loktevogo sustava [Long-term results of treatment of children with the elbow contractures]. Genij Ortopedii, 2012, no. 2, pp. 94-98. (in Russian)

15.Stein D.A., Patel R., Egol K.A., Kaplan F.T., Tejwani N.C., Koval K.J. Prevention of heterotopic ossification at the elbow following trauma using radiation therapy. Bull. Hosp. Jt. Dis., 2003, vol. 61, no. 3-4, pp. 151-154.

16.Chibirov G.M., Soldatov Iu.P. Lechenie bolnykh c narusheniem funktsii loktevogo sustava, soprovozhdaiushchimsia posttravmaticheskim psevdoartrozom myshchelka plechevoi kosti [Treatment of patients with the elbow function disorder accompanied by posttraumatic pseudoarthrosis of humeral condyle]. Genij Ortopedii, 2013, no. 3, pp. 80-81. (in Russian) 
17.Stans A.A., Maritz N.G., O'Driscoll S.W., Morrey B.F. Operative treatment of elbow contracture in patients twenty-one years of age or younger. J. Bone Joint Surg. Am., 2002, vol. 84, no. 3, pp. 382-387. DOI: 10.2106/00004623-200203000-00008.

18.Piper S.L., Lattanza L.L., Shen T.S., Wall L.B., Goldfarb C.A. Open Surgical Release of Posttraumatic Elbow Contracture in Children and Adolescents. J. Pediatr. Orthop., 2019, vol. 39, no. 5, pp. 241-246. DOI: 10.1097/BPO.0000000000000923.

19.Silva J.F. The problems relating to old dislocations and the restriction on elbow movement. Acta Orthop. Belg., 1975, vol. 41, no. 4, pp. 399-411.

20.Sneftrup S.B., Jensen S.L., Johannsen H.V., Søjbjerg J.O. Revision of failed total elbow arthroplasty with use of a linked implant. J. Bone Joint Surg. Br., 2006, vol. 88, no. 1, pp. 78-83. DOI: 10.1302/0301-620X.88B1.16446.

21.Turakulov Sh.Kh. Artroplastika loktevogo sustava s ispolzovaniem allogennykh khriashchevykh transplantatov $i$ sharnirnodistraktsionnykh apparatov (eksperimentalno-klinicheskie issledovaniia). Avtoref. diss. ... kand. med. nauk [The elbow arthroplasty using allogenous cartilage grafts and hinge-distraction devices (experimental-and-clinical studies). Cand. med. sci. diss. abstr.]. M., 1987, 21 p. (in Russian)

22.Ek E.T.H., Paul S.K., Hotchkiss R.N. Outcomes after operative treatment of elbow contractures in the pediatric and adolescent population. J. Shoulder Elbow Surg., 2016, vol. 25, no. 12, pp. 2066-2070. DOI: 10.1016/j.jse.2016.09.008.

The article was submitted 10.03.2020; approved after reviewing 20.05.2020; accepted for publication 23.08.2021.

\section{Information about the authors:}

1. Gairat D. Bayimbetov - Candidate of Medical Sciences, g.baimbetov@yandex.ru;

2. Iskandar Yu. Khodzhanov - Doctor of Medical Sciences, Professor, Prof.Khodjanov@mail.ru. 